\title{
FACTORS OF APPLICATION FOR MARRIAGE ISBAT AT THE RELIGIOUS COURT OF SUNGGUMINASA GOWA
}

\author{
Abdul Salam ${ }^{1}$ \\ Moh. Saleh Ridwan ${ }^{2}$ \\ M. Tahir Maloko ${ }^{3}$ \\ STAI Al-Azhar Gowa ${ }^{1}$ \\ Faculty of Islamic Law UIN Alauddin Makassar ${ }^{2,3}$ \\ abdulsalamkendari93@gmail.com¹, salriduin@gmail.com², \\ thahir.maloko@uin-alauddin.ac.id ${ }^{3}$
}

\begin{abstract}
This paper discusses the factors for submitting an application for marriage isbat at the Gowa Sungguminasa Religious Court. This type of research is a descriptive qualitative field research. In this study, using primary, secondary and tertiary data sources. Furthermore, the data collection methods used were observation, interviews and documentation. Data processing and analysis techniques are carried out through three stages, namely: data reduction, data display, and conclusion drawing/vervication. The results of the study indicate that the main factor causing the parties to apply for Isbat Marriage at the Religious Court of Sungguminasa Gowa is the existence of urgent interests related to legal administration, for example taking care of veterans' benefits, taking care of their child's birth certificate. Therefore, it is expected that teenagers or prospective brides before deciding to get married should have knowledge about marriage, knowledge of building a good household according to Islamic teachings, and ensure all administration related to marriage is completed first, because if the administration is not completed then this will have an impact on the future of the bride and groom, including their descendants.
\end{abstract}

Keywords: Isbat Nikah; Sungguminasa Religious Court

\section{PRELIMINARY}

Marriage is an important thing in the reality of human life. Marriage contracts in Islamic law are not merely civil matters, but are sacred bonds related to belief and faith in Allah swt. Thus there is a dimension of worship in a marriage. ${ }^{1}$ In the context of Indonesia, which is a state of law, all problems must be resolved legally. No different from problems related to marriage, everything has been regulated and set forth in the form of law.

Marriage is said to be valid if it is carried out according to the law of each religion and belief and every marriage must also be recorded according to the applicable laws and regulations (Article 2 of Law Number 1 of 1974 concerning marriage). There is a tendency to interpret that marriage is legal if it is carried out according to each religion and belief, while recording is an administrative requirement only. Whether or not a registration is carried out does not constitute a defect or more firmly does not cause the marriage to be invalid.

${ }^{1}$ Amiur Nuruddin and Azhari Akmal Tarigan, Islamic Civil Law in Indonesia (Cet. I; Jakarta: PT Kencana, 2004), p.206. 
This is evidenced by the fact that there are still many people who carry out an underhand marriage, that is, the marriage is only carried out according to the laws of each religion and belief, not recorded at the Office of Religious Affairs (KUA). Marriages that are not recorded in the end often experience problems, this is because a marriage cannot be recognized without evidence of a Marriage Certificate from the Office of Religious Affairs. In this case, you can submit an application for Isbat Marriage to the Religious Court, because the implementation of Isbat Nikah can be carried out in the Religious Court.

Judicial institutions which are included in the Religious Courts aim to uphold law and justice based on the law in the life of the state, therefore this institution cannot be separated from the State. ${ }^{2}$ According to Yahya Harahap, the enactment of the Law on Religious Courts Number 7 of 1989 which was promulgated on December 29, 1989, has brought clarity and clarity to the functions and powers of the Religious Courts as one of the judicial bodies implementing judicial power. Because when viewed from the point of view of the purpose of its birth, this law intends to identify and make positive what areas of civil law are within the jurisdiction of the Religious Courts, especially dealing with the General Courts. ${ }^{3}$ Meanwhile, according to Daniel S. Lev, the Court is a symbol of power and the Religious Court is a symbol of Islamic power.

The authority of the Religious Courts, which is the first level judicial body, is to accept, examine, decide and settle cases of marriage, inheritance, wills, grants, waqf, zakat, infaq, sadaqah and sharia economics, which includes the Isbat of Marriage between people who are Muslim. ${ }^{4}$

In general, the issue of marriage is regulated in Law No.1 of 1974 concerning Marriage which is the material legal source of marriage. Along with the development of the times the Act began to show its weaknesses. Basically Law no. 1 of 1974 concerning Marriage is a material law in the judicial environment, but currently in court cases it does not fully refer to the Act. For example in the matter of marriage isbat, in the Compilation of Islamic Law Article 7 paragraph (3d) it is explained that the marriage isbat submitted to the Religious Courts is limited when there is a marriage that occurred before the enactment of Law no. 1 of $1974 .^{5}$ This means that if it refers to the Compilation of Islamic Law in Article 7 paragraph (3d) and Law No.1 of 1974 when a person married before the marriage law was enacted (before 1974) then it is allowed to do isbat marriage, because at that time it was not There are rules regarding registration of marriages. After the existence of the law, parties who marry siri (marriage under the hand) are prohibited from doing isbat marriage.

The fact that is currently happening is that there are many cases of marriage isbat that are included in the Religious Courts environment, even though Siri's marriage occurred after Law no. 1 of 1974. One of the main objectives of the enactment of Law no. 1 of 1974 is an effort to control the law on marriages carried out by the people of

\footnotetext{
${ }^{2}$ Rifyal Kaaba, Enforcement of Islamic Law in Indonesia (Cet. I; Jakarta: Khairul Bayan, 2004), p. 112.

${ }^{3}$ Yahya Harahap, Position of Authority and Procedures for Religious Courts (Cet. V; Jakarta: Sinar Graphic, 2009), p. 5.

${ }^{4}$ Ahmad Mujahidin, Renewal of the Procedural Law of Religious Courts (Cet. II; Bogor: Ghalia Indonesia, 2014), p. 25.

${ }^{5}$ Nuansa Aulia Editorial Team, Compilation of Islamic Law (Cet. I; Bandung: Nuansa Aulia, 2008), p. 3.
} 
Indonesia. One of the efforts made by the Indonesian government is to register marriages, which aims to create order in marriage in society. ${ }^{6}$ With this marriage registration, as a consequence, the community will get legal recognition by law for the marriage and will get legal protection if one day there is a legal dispute related to divorce, inheritance distribution, endowments, and so on.

\section{THEORETICAL STUDY}

\section{A. Understanding Isbat Marriage}

Isbat marriage comes from Arabic which consists of isbat and marriage. According to the language isbat means "determination, confirmation and affirmation" Isbat Nikah in Indonesian is known as isbat nikah which is defined by the confirmation and determination of marriage through recording in an effort to get the ratification of a marriage according to applicable law.

Specifically regarding marriage cases, in the elucidation of article 49 letter (a) it is stated that: "what is meant by "marriage" are matters regulated in or based on the applicable law regarding marriage which is carried out according to sharia, among others in number (22) the case states "statements regarding the validity of marriages that occurred before Law Number 1 of 1974 concerning marriages carried out according to other regulations". henceforth, this case is referred to as a marriage ratification case which in the compilation of Islamic law is qualified as a legal remedy called isbat nikah.

\section{B. Marriage Registration and Legal Basis of Marriage Isbat}

The main source in making conclusions about Islamic law is based on a careful analysis of the texts of the Qur'an and Hadith. Besides these two sources, there are other supporting sources that can also be used as the basis for legal analysis of a problem such as Qiyas, ijma and so on. ${ }^{8}$ Such supporting sources remain based on the Qur'an and hadith as the main sources.

Islamic law, both in the Qur'an and Hadith, does not concretely regulate the existence of marriage registration. So far, Muslims still adhere to an understanding that emphasizes a fiqh-centric perspective in the implementation of marriage. According to the understanding of this version, marriage is sufficient if the terms and pillars according to the provisions of fiqh are fulfilled, without the registration of marriage being followed. This is different from the muamalah verse which is ordered to record it.

There are several analyzes that can be put forward why fiqh does not give serious attention to marriage registration, even though there are verses in the Qur'an that recommend recording all forms of muamalah transactions. First; forbidden to write anything other than the Qur'an. As a result, the written culture is less developed than the rote culture. Second; when it relied heavily on memorization. Remembering a wedding event is not a difficult thing to do. Third; the tradition of walimah al ulrsy (albeit very

${ }^{6}$ Zainuddin Ali, Islamic Civil Law in Indonesia (Cet. I; Jakarta; Sinar Graphic, 2006), p. 26.

${ }^{7}$ Ahmad Warson Munawwir, Al-Munawwir Arabic-Indonesian Dictionary (Yogyakarta, 1984), p. 157 .

${ }^{8}$ In the terminology of ushul fiqh, there are four sources of Islamic law or commonly called aladillah al-syariah, namely: al-Qur'an, Sunnah, Ijma, and Qiyas. While what is not agreed upon is istihsan, Maslahah al-Mursala, Al-Istishab, Al-Urf, Qaul/Mazhab al-Sahabi and syar'u man qablana. For details see Abdul Wahab Khallaf, The Science of Usul Fiqh (Cet. XII; Cairo: Dar al-Kalam, 1978), p. 21-22. 
simply: with a goat) is a witness in addition to the syar'i witness of a marriage. Fourth; there is an impression that marriages that took place in the early days of Islam had not yet occurred between regions of different countries. ${ }^{9}$ Due to the demands of development, with various considerations of benefit, Islamic law in Indonesia regulates it. As stated in the Indonesian law. No. 1 of 1974 concerning marriage, article 2 paragraph (2).

Marriage registration aims to realize the orderliness of marriage in society. This is an effort that is regulated through legislation, to protect the dignity and sanctity of marriage, more specifically for women in domestic life. Through marriage registration as evidenced by a marriage certificate, each husband and wife gets a copy, if there is a dispute between them, or one of them is not responsible, then the other can take legal action to maintain or obtain their respective rights. Because with the deed, husband and wife have authentic evidence of the legal actions they have done. ${ }^{10}$

Law No. 22 of 1946, dated November 21, which has been in effect since November 2, 1954 through Law no. 32 of 1954, dated October 26, 1954 (LN. 1954 No. 98 ), namely the law on registration of marriages, divorces and reconciliations regulates the registration of marriages, divorces and reconciliations in Indonesia for Muslims. In article 1 of Law no. 22 of 1946 determined that: ${ }^{11}$ Marriages carried out according to the Islamic religion are supervised by a marriage registrar appointed by the Minister of Religion or an employee appointed by him.

In the development of Law no. 1 of 1974 concerning marriage places the registration of a marriage in an important place as proof that the marriage has been held. This is requested by article 2 paragraph (2) which states that: every marriage is recorded according to the applicable law.

Certain formalities required for a marriage to take place are regulated in Articles 3 -11 of PP No. 9 of 1975, namely:

1. Informing the intention to carry out the marriage to the registrar at the place where the marriage will take place Article (3)

2. Article (8) There is an announcement held by the registrar at the marriage registrar's office regarding the intention to carry out the marriage.

3. The marriage must be carried out in front of the registrar, who is attended by two witnesses by observing the marriage procedure according to the law of each religion and belief (Article 10).

4. Immediately after the marriage, the bride and groom are required to sign a marriage certificate, which is followed by two witnesses, the registrar, and the marriage guardian or his representative for those who are Muslim (Article 11)

5. To provide legal certainty regarding the existence of a marriage, the bride and groom are given a marriage certificate / marriage certificate as evidence (Article 12)

\footnotetext{
${ }^{9}$ Amir Nuruddin, Civil Law in Indonesia (Jakarta: Kencana, 2004), p. 121.

${ }^{10}$ Ahmad Rofiq, Islamic Law in Indonesia (Cet. VI; Jakarta: Raja Grafindo Persada, 2003), p.

${ }^{11}$ Abd. Shomad, Islamic Law (Cet. II; Jakarta: Kencana, 2012), p. 280.
} 107. 
For those who do not register their marriages or who are reluctant to marry before a marriage registrar, they will bear the legal risk, their marriages are qualified as illegal marriages in the form of cohabitation or compassionate marriages.

Registration is not something that determines whether a marriage is legal or not. Marriage is legal if it has been carried out according to the provisions of his religion, even though it is not or has not been registered. In the decision of the high Islamic court in 1953 No. 23/19 confirms that if the pillars of marriage are complete, but not registered, then the marriage is valid, while the person concerned is subject to a fine for not registering the marriage.

7, namely:

In the compilation of Islamic law, this recording issue is regulated in articles 5-

\section{Article 5}

a. In order to ensure the orderliness of marriage for the Islamic community, every marriage must be recorded.

b. Marriage registration in paragraph (1) is carried out by a marriage registrar as regulated in Law no. 22 of 1946 jo. Law No. 32 of 1954.

\section{Article 6}

a. To fulfill the provisions in Article 5, every marriage must be held before and under the supervision of a marriage registrar.

b. Marriages that are carried out outside the supervision of the marriage registrar do not have legal force.

Article 99 of the Egyptian Law of 1931 contains provisions that: it is unacceptable if there is a denial of the acknowledgment of the existence of a marriage or a statement that has been married unless it is proven by an official marriage certificate.

In the compilation of Islamic Law article 4 it is explained that:

Marriage is legal, if it is carried out according to Islamic law in accordance with Article 2 paragraph (1) of Law no. 1 of 1974 concerning marriage. Furthermore, Article 5 explains that:

a. In order to ensure the orderliness of marriage for the Islamic community, every marriage must be recorded.

b. The registration of the marriage referred to in paragraph (1) is carried out by the marriage registrar as stipulated in Law no. 22 of 1946 jo. Law No. 32 of 1954.

\section{Article 6}

a. In order to fulfill the provisions in Article 5, every marriage must take place before and under the supervision of a marriage registrar.

b. Marriages carried out outside the supervision of the marriage registrar do not have legal force.

KHI emphasizes that marriage is legal if it is carried out according to the law of the religion. As in article 2 paragraph (1) of Law no. 1 of 1974, namely: "Marriage is legal, if it is carried out according to each religion and belief." With this, marriages carried out by Muslims will be valid if they are carried out according to the marriage rules in Islam. In a contrario, marriages carried out by Muslims without being based on 
marriage rules in Islam are invalid (compare with Arso Sosroatmodjo and A Wasit Aulawi, 1975:37). ${ }^{12}$

Marriage registration required by article 5 of the KHI is in line with what is stipulated in article 2 paragraph (2) of Law no. 1 of 1974, namely: every marriage is recorded according to the applicable laws and regulations.

Formalities relating to marriage registration are regulated in PP no. 9 of 1974 concerning marriage (LN, 1975 No. 12). The regulation on marriage registration has also been regulated in Law no. 22 of 1946 which took effect on November 2, 1954 through Law no. 32 of 1954, namely the Law on Marriage Registration, Divorce, and Reconciliation. Marriages that are carried out without a recording procedure are known as sirri marriages.

Sirri marriage according to KHI has no legal force. Sirri marriages are categorized as illegitimate marriages in the form of Kompassianate Marriage or buffalo gatherings (Yahya, 1991:44). Sirri marriages are legal according to religion, but their rights are not guaranteed by laws and regulations. If during the sirri marriage a child is born, then the child is considered illegitimate by law, so that he only has a civil relationship with his mother, in other words, the child has no legal force (not recognized if a civil problem arises).

Article 4-7 is an explanation of the fundamental juridical emphasis on marriage as regulated in Article 2 of Law no. 1 of 1974 (Yahya 1991: 43). One of the points of this emphasis is that marriage can only be proven by a marriage certificate made by PPN (Article 7 paragraph (1) KHI).

In this latest development, the presence of the penghulu in the wedding ceremony as the executor of the marriage legislation is required in Muslim countries. The absence of a marriage registrar in a marriage ceremony can cause the person who organized the marriage to be punished, in some countries, while the marriage itself (which is then registered) is not annulled.

In Muslim countries it is required to have a marriage registration according to the laws and regulations in force in each country, although it is not a pillar of marriage, it is considered very important to prove a valid marriage by someone.

Apart from the marriage itself, it must be recorded, documents related to the marriage must be kept, documented for the sake of proof if doubts or problems arise in the future.

Taking into account the legal provisions governing marriage registration, it can be understood that the existence of such registration is to create order related to state administration which is expected to lead to the creation of social order. With the orderly state administration, it is hoped that marriage events in Indonesia can be controlled so that no parties (especially women) are harmed. In other words, laws and regulations are not made without purpose. ${ }^{13}$

To understand the law of sirri marriage, including the law concerning marriage registration, the qias approach can be used. ${ }^{14}$ Qias is carried out if there is a case

${ }^{12}$ Abd. Shomad, Islamic Law, p. 284.

${ }^{13}$ See Imam Syaukani, Reconstruction of the Epistemology of Indonesian Islamic Law and Its Relevance for the Development of National Law (Jakarta: PT Raja Grafindo Persada, 2006), p. 252-253.

${ }^{14} \mathrm{Kias}$ is one of the recognized approaches in ushul fiqh etymologically the word "kias" means "equating, comparing, or measuring" epistemologically, the ushul fiqh scholars define kias as "stipulating 
(problem), such as an incident or event that needs to be legalized, it is necessary to look for another event that has a legal stipulation on the basis of the texts and between these two cases there is an illat equation. ${ }^{15}$

Furthermore, qias analysis will be used in focusing the discussion on the law of marriage registration, namely doing qias between recording in the marriage contract and recording in the muamalah contract. Both can be interpreted because marriage is also an act that falls into the category of muamalah practice. ${ }^{16}$ The text that stipulates the obligatory law of recording in muamalah is QS Al-Baqarah/2:282.

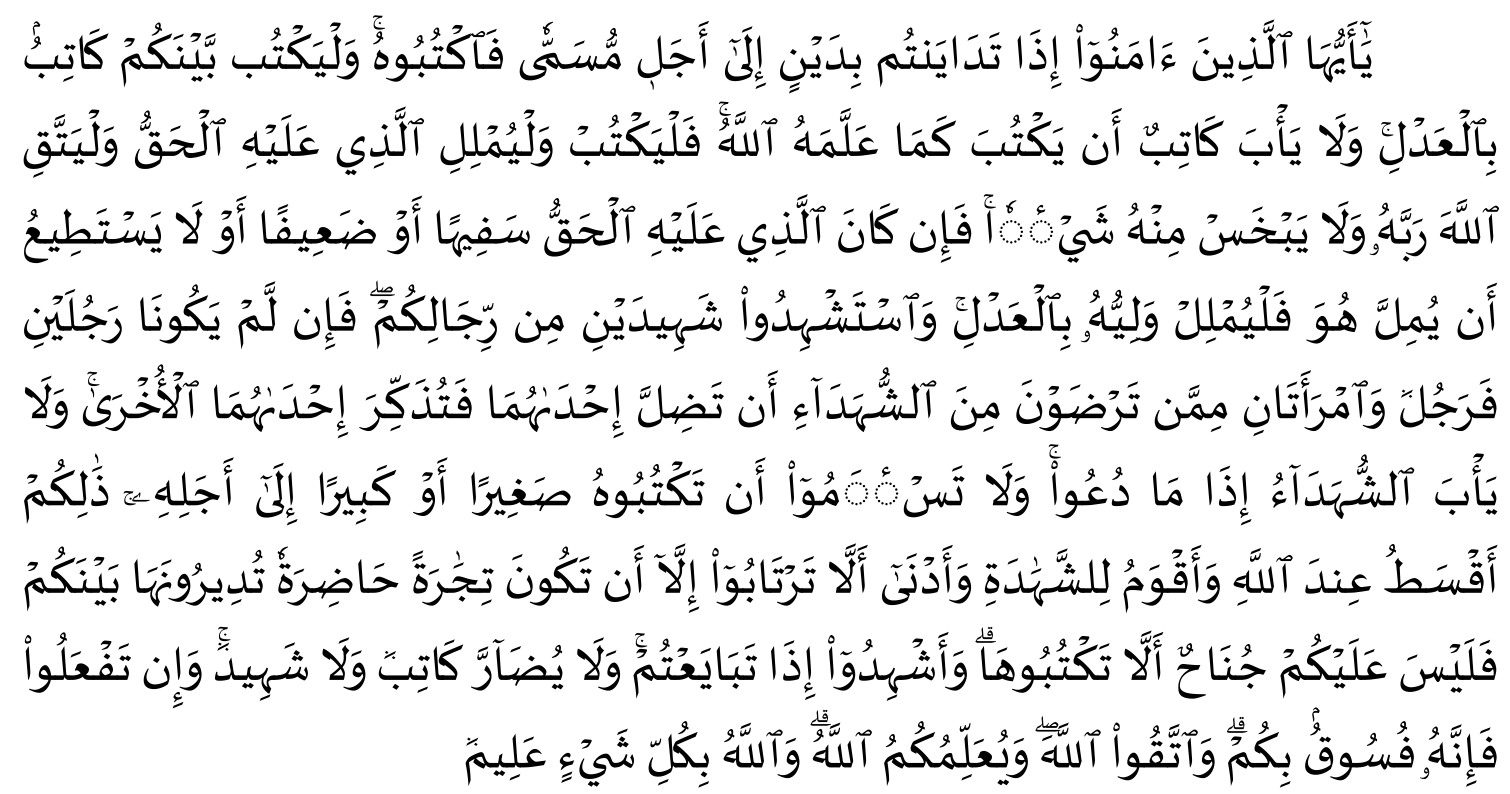

The translation:

"O you who believe, if you do mu'amalah not in cash for a specified time, then you should write it down. and let a writer among you write it rightly. and let the writer not be reluctant to write it down as Allah taught it, let him write, and let the debtor obey (what is to be written), and let him fear Allah his Lord, and let him not reduce anything from his debt. If the debtor is a person who is weak in mind or weak (his condition) or he himself is not able to enforce it, then let his guardian be honest. and bear witness with two witnesses from the men (among you). if there are no two men, So (permissible) a man and two women from the witnesses you are pleased with, so that if one forgets, the other reminds him. the

the law of an event or event that has no textual basis, namely by how to compare it to an event or other event whose law has been determined based on the text because there are illat similarities between the two events or events.

${ }^{15}$ There is a difference between the editors of ushul fiqh scholars in defining illat, the majority of the Hanafi school of scholars, some of the Hambali scholars and Imam al-Baidawi (one of the scholars of the Shafii school, said that illat is an attribute (which functions) as an identifier for a law, if there is illat in a case, then the law also exists. The word "identifying nature" in the above definition is meant as a sign or indication of the existence of a law, not law. For example, intoxication is an illat in drinking alcohol, and intoxication is a sign or indication or cause of a law, namely the prohibition of drinking khamer.

${ }^{16}$ In the understanding of Islam, there are two kinds of practice of a Muslim, namely worship and muamalah. Worship is a direct relationship between a servant and his Lord, while Muamalah is a relationship between fellow servants of Allah. 
witnesses should not be reluctant (to testify) when they are summoned; and do not get tired of writing down the debt, whether small or large, until the deadline for paying it. that is more just in the sight of Allah and strengthens your testimony and is closer to not (causing) your doubts. (Write your mu'amalah), unless it is a cash trade that you carry out among yourselves, then there is no sin for you, (if) you do not write it down. and bear witness when you buy and sell; and let not the writer and the witness make it difficult for each other. if you do (that is), then verily it is an act of disobedience to you. and fear Allah; God teaches you; and Allah knows all things."

This verse explains the order to record in writing in all forms of muamalah affairs in order to strengthen the testimony, as well as to avoid doubts.

The word اينتم (tadayantum) in the verse is translated with muamalah, derived from the word (Dain). This word has many meanings, but the meaning of each word that is assembled by the letters of the word dain (dal, ya, nun) always describes the relationship between two parties. This word, among others, means debt, vengeance, kataatan, and religion. Everything describes a reciprocal relationship, or in other words bermuamalah. ${ }^{17}$

Thus, it can be understood that what is meant by debt is not only accounts payable, but is of a general nature which describes a reciprocal relationship. So that the marriage bond is also referred to in this verse. Even the marriage bond is a reciprocal relationship that is much stronger than just debt. as mentioned in QS An-Nisa/4:21 as misaqangalizan which means a strong agreement. This implies that marriage in Islam is something sacred, it should not be toyed with, because marriage is not only an outward engagement but also an inner one.

If the debt contract or other working relationship must be registered, the marriage contract that is so noble, noble, and sacred is even more important to be recorded. Thus, registering a marriage contains benefits or benefits in people's lives. On the other hand, if the marriage is not clearly regulated through laws and regulations and is not registered, it will be used by the parties to the marriage only for personal interests and to the detriment of other parties, especially the wife and children.

With the existence of written evidence of each party related to this contract, it can avoid the complexity of problems later (after the contract period has passed). Because when they are faced with a problem later, they don't need to worry because there is evidence to support it. In contrast to oral evidence, its accuracy and validation are debatable. Thus the verse implies that the existence of authentic evidence is very much needed to maintain legal certainty. Even the editors clearly describe that recording takes precedence over testimony, which is one of the pillars of marriage.

After having put forward the text which is the basis of reference for analyzing the law of marriage registration, then look for illat which are both contained in the marriage contract and muamalah contract, namely the existence of abuse or harm if there is no written evidence that shows the validity of the contract. This written evidence is the strongest evidence of the bond between the two parties in an agreement. Even in a marriage contract, it should be prioritized because in a muamalah contract, usually what is contracted is the right to goods, while the contract in a marriage that is contracted is the right to the self/soul. The right to self is much more important because

${ }^{17}$ Quraish Shihab, Tafsir Al-Misbah; Message, Impression, and Harmony of the Qur'an, Volume I (Cet. V; Jakarta: Lentera Hati, 2006), p. 603. 
it involves the self-interest of husband and wife, so the existence of evidence in the marriage contract is very important for the couple. Therefore,

Marriage should be projected to prevent harm that will occur if household development is not managed properly and responsibly. As the rules of fiqh proposal state:

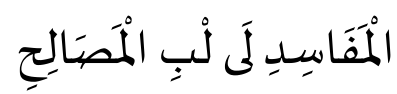

Meaning

"Avoiding mufsada/harm is far more important than fulfilling the benefit"

The purpose of this rule is that the law of an action is not solely based on seeking benefit, but what is far more important is to avoid the negative impact (disadvantage) of the act.

Based on these rules, it can be said that the existing sirri marriages in fact cause a lot of harm and should be avoided. Marriage is carried out as usual, it is far more beneficial and can avoid the harm. Marriage is not enough just to have an oral contract between the two parties (the prospective groom and the prospective bride), but what is far more important is to register the marriage contract in order to obtain valid written evidence.

Marriage registration can also function as a "regulator" of the traffic of polygamous practices which are often carried out secretly by certain parties who only use sirri marriages as a means of polygamy (more than one wife) or polyandry (more than one husband). Every couple who will get married at the Office of Religious Affairs (KUA) or the Civil Registry Office (KCS) usually has to go through the mechanism for announcing the status of the prospective bride and groom after being registered as a married couple. When the status data of each prospective bride and groom is announced and it turns out that there are objections, the marriage may be annulled.

Before the unwanted legal consequences occur, it is better for couples who are married in a sirri to immediately record their marriage, in positive law it has been regulated about this, the recording management for couples who are married in a sirri is still differentiated based on two groups, namely for those who are Muslim and those who are Muslim. are non-Muslims, because as regulated in Article 2 paragraphs (1) and (2) it is stated that for those who are Muslim, the registration is carried out by the marriage registrar, divorce, reconciliation, while for non-Muslims, the recording is done at the civil registry office.

In particular, the registration for Muslims is based on the applicable provisions in the compilation of Islamic law (KHI). According to KHI, article 7 paragraph (1), ideally a marriage must be proven by the existence of a marriage certificate made by a marriage registrar (PPN). However, if a marriage has not been officially registered, the next verse clearly regulates it. This provision is definitely necessary for those who have been married in a sirri way.

\section{Conditions for Isbat Marriage}

Based on the provisions of the KHI, marriages that are not registered or cannot be proven by the existence of a marriage certificate, then for married couples who are Muslim can take a path that has been recognized as valid, namely through "isbat nikah" (re-determination of the marriage contract). In this case, Article 7 paragraph (2) of the KHI states, as mentioned above, namely: "In the event that the marriage cannot be 
proven by a marriage contract, the marriage isbat can be submitted to the Religious Court"

The conditions for Isbat Marriage can only be proven by a marriage certificate made by the Marriage Registrar. As for the conditions for marriage isbat as described in the Compilation of Islamic Law in article 7 paragraph 3, namely:

1. The existence of marriage in the context of divorce settlement

2. Loss of marriage certificate

3. There are doubts about whether or not one of the conditions of marriage is valid

4. The existence of marriages that occurred before the enactment of Law No. 1 of 1974 and

5. Marriages carried out by those who do not have marriage barriers according to Law No. 1 of 1974.

Isbat marriage can only be done if one or more of the above conditions are met. For couples who are married in a sirri manner who will propose isbat, point c (there are doubts about whether or not one of the conditions of marriage) can be the reason for determining the isbat.

As explained in the previous discussion, sirri marriages tend to contain the meaning of marriages that have not fully met the legal requirements of a marriage, perhaps also including its pillars. That is, if the conditions for guardians, witnesses, and other conditions, including the aspect of announcing it, then the marriage contract can be considered not to have fulfilled the legal provisions of the marriage. Therefore, in order for a marriage to be fully considered valid, it should be determined through isbat. So that they can record it officially.

Paragraph (4) of the same article emphasizes that those who are entitled to apply for an isbat for marriage are husband or wife, their children, marriage guardians, and parties with an interest in the marriage. This means that the party who proposes isbat is not limited to husband and wife, but also includes anyone who is directly related to the marriage bond. In addition to recording, the husband and wife are also allowed to remarry if it is felt that marriage isbat alone is not enough. Remarriage for married couples who are Muslim is not required.

Meanwhile, for married couples who are non-Muslim, guidelines such as isbat do not exist or are not regulated. Instead, they were asked to re-marry which was then accompanied by a record of it before the authorized official, namely at the civil registry office. Remarriage is carried out because the marriage law does not regulate other than this possibility.

Luckily for those who are Muslims, there are provisions in the KHI law that regulate the isbat of marriage. So that the way is still open to legalize marriages that are carried out in a sirri or hand-to-hand marriage. On the other hand, the existence of these provisions has provided an opportunity for the opening of sirri marriages, as well as providing an opportunity for ratification of marriages and obtaining a marriage certificate preceded by an unregistered marriage (sirri marriage). However, with the marriage isbat at least it appears that there is good faith from the perpetrators of the sirri marriage. With the registration of marriages, couples who were previously married in a sirri way now no longer have to worry about the impact of unregistered marriages. The marriage certificate which is the result of the registration they can use to take care of 
matters that are very important for the future of the couple. Especially for administrative matters and the future of their children.

\section{The Purpose of Marriage Isbat}

According to the applicable laws and regulations and the Compilation of Islamic Law Article 7 states that a marriage can only be proven by a marriage certificate, meaning that in the case of a marriage not getting a marriage certificate, the solution that can be followed is to apply for a marriage isbat, with the aim that the marriage that is carried out is legally proven. authentic in the form of a marriage certificate and received legalization both legally and formally for the wider community. In addition, to avoid slander that can occur at any time in everyday life in the community, the direct impact of which is on women in general.

Isbat marriage becomes the authority of the Religious Courts is a wise solution to solve problems in society, in addition to being one of the functions of the law is to regulate and provide protection for the rights of the community, therefore the registration and marriage isbat aims to create marriage order in a society that is implications for efforts to protect the rights of those involved in the marriage. ${ }^{18}$

\section{III.RESEARCH METHODOLOGY}

This type of research is a descriptive qualitative field research. In this study, using primary, secondary and tertiary data sources. Furthermore, the data collection methods used were observation, interviews and documentation. Data processing and analysis techniques are carried out through three stages, namely: data reduction, data display, and conclusion drawing/vervication.

\section{IV.RESEARCH RESULTS AND DISCUSSION}

The legal provisions governing marriages that are justified by law are as regulated in Law Number 1 of 1974 Article 2 paragraph (1) that a marriage is valid according to law if the marriage is carried out according to each religion and belief. 2) determine that each marriage is recorded according to the prevailing laws and regulations.

In several articles of the Compilation of Islamic Law, it is stated that: Article 5: Paragraph (1); In order to ensure the orderliness of marriage for the Islamic community, every marriage must be recorded.

"So there is a birth certificate without a marriage certificate, the birth certificate is questioned, how to deal with it means there is a game inside, because it is not allowed, because many people come to apply for marriage certificates because their child's birth contract cannot be made, so there should no longer be a reason for people to get married. under the hands and not reporting to the KUA, because the government has prepared for every kelurahan to have a KUA and the KUA provides recommendations to the local PPN, so there is no longer any reason not to say a word of marriage, unless the case is elopement." 19 2004), p. 86.

${ }^{18}$ Satria Efendi M Zein, Contemporary Islamic Family Law Problems (Jakarta: Pranada Media,

${ }^{19}$ Fahima (51 years), Judge of the Religious Court of Sungguminasa Gowa, Interview, Gowa, 9 August 2019. 
The statement is in accordance with Article 6: Paragraph (2); KHI or Law no. 1/1974 Marriage which is carried out outside the supervision of the Marriage Registrar does not have legal force. Article 7: Paragraph (1); Marriage can only be proven by a Marriage Certificate made by the Marriage Registrar. Paragraph (2); In the event that the marriage cannot be proven by a Marriage Agreement, the Isbat of Marriage can be submitted to the Religious Court. Paragraph (4); Those who are entitled to apply for Isbat Marriage are husband or wife, their children, marriage guardians and parties with an interest in the marriage.

From these provisions, it can be seen that the Isbat Nikah can only be submitted through the Religious Court, in the area where the applicant lives. Isbat Marriage is something that is very important in social lifeso that it is regulated through legislation, both Law Number 1 of 1974 and through the Compilation of Islamic Law. Marriage registration aims to create marital order in society. Marriage registration is an effort to maintain the sanctity of the legal aspects arising from the marriage bond. The realization of the recording resulted in the birth of a Marriage Certificate, each of which was owned by the wife and husband. The deed can be used by each party if someone feels aggrieved from the existence of the marriage bond to get their rights.

"So a person's interest is no longer enough just with words that mean marriage but must be recorded, in the case of a legal marriage, but legally the law is not valid which will cause the rights of the person to be not protected by law due to his marriage. not recorded. So if someone comes to take the marriage isbat, it actually violates the rules, but because of conditions such as his child a birth certificate must be made, then the court gives the marriage isbat." 20

Gowa Regency is an area where there are still many marriages that are not recorded by the Marriage Registrar, both marriages before Law Number 1 of 1974 and after the existence of the law. This is evidenced by the number of Isbat Marriage cases that go to the Gowa Sungguminasa Religious Court.

In connection with the number of Isbat Marriage cases that go to the Religious Court of Sungguminasa Gowa, then among the causes or reasons for the parties to apply for Isbat Marriage, First, the community considers the cost of marriage to be quite expensive. Second, people who apply for isbat marriage are those who have not yet reached the age of marriage. Third, many people who apply for isbat marriage due to geographical conditions, for example, Gowa district with very extreme geographical conditions, namely people who live in the mountains no longer have time to take care of the KUA. Fourth, Doubt whether the marriage is legal or not so that it remains to take care of the court. Fifth, people who take care of marriage isbat to the Religious Courts because they just want to get divorced, so a marriage certificate is required, because they can't divorce if they don't have a marriage certificate. ${ }^{21}$.

In general, it can also be seen that the reason why people apply for marriage isbat is because people do not understand the rules of the law, especially the marriage isbat law.

"There are two possibilities that cause people to report, the first possibility is that the respective village priests report only and the imam himself does not report to

\footnotetext{
${ }^{20}$ Fahima (51 years), Judge of the Religious Court of Sungguminasa Gowa, Interview, Gowa, 9 August 2019.

${ }^{21}$ Muhammad Fitrah (38 years), Judge of the Religious Court of Sungguminasa Gowa, Interview, Gowa, August 6, 2019.
} 
the Marriage Registrar (PPN); Second, most people really don't know that they have to report if they want to get married."22

The explanation above shows that the level of public understanding of the marriage process is still low. This shows that the role and function of religious instructors in providing understanding to the community is not running optimally.

\section{CLOSING}

Based on the explanation above, it can be concluded that the main factor causing the parties to apply for Isbat Nikah at the Religious Court of Sungguminasa Gowa is the existence of urgent interests related to legal administration, for example taking care of veteran's allowances, taking care of their children's birth certificates. Therefore, it is expected that teenagers or prospective brides before deciding to get married should have knowledge about marriage, knowledge of building a good household according to Islamic teachings, and ensure all administration related to marriage is completed first, because if the administration is not completed then this will impact on the future of the bride and groom, including their descendants.

\section{BIBLIOGRAPHY}

Nuruddin, Amiur and Azhari Akmal Tarigan, Islamic Civil Law in IndonesiaCet. I; Jakarta: PT Kencana, 2004.

Kaaba, Rifyal, Enforcement of Islamic Law in Indonesia Cet. I; Jakarta: Khairul Bayan, 2004.

Harahap, Yahya, Position of Authority and Procedures for Religious CourtsCet. V; Jakarta: Sinar Graphic, 2009.

Mujahidin, Ahmad, Renewal of the Procedural Law of the Religious Courts Cet. II; Bogor: Ghalia Indonesia, 2014.

Nuansa Aulia editorial team, Islamic Law Compilation Cet. I; Bandung: Nuances Aulia, 2008.

Ali, Zainuddin, Islamic Civil Law in Indonesia, Cet. I; Jakarta; Sinar Graphic, 2006.

Munawwir, Ahmad Warson, Al-Munawwir Arabic-Indonesian Dictionary, Yogyakarta, 1984.

Khalaf, Abdul Wahab, Usul Fiqh Science. XII; Cairo: Dar al-Kalam, 1978.

Nuruddin Amir, Civil Law in Indonesia, Jakarta: Kencana, 2004.

${ }^{22}$ M. Thayyib HP. (49 years old), Religious Court Judge Sungguminasa Gowa, "Interview” on August 8, 2019. 
Rofiq, Ahmad, Islamic Law in Indonesia, Cet. VI; Jakarta: Raja Grafindo Persada, 2003.

Shomad, Abd., Islamic Law Cet. II; Jakarta: Kencana, 2012.

Syaukani, Imam, Reconstruction of the Epistemology of Indonesian Islamic Law and Its Relevance for the Development of National Law, Jakarta: PT Raja Grafindo Persada, 2006.

Shihab, Quraish, Tafsir Al-Misbah; Message, Impression, and Harmony of the Qur'an, Volume I Cet. V; Jakarta: Heart Lantern, 2006.

Zein, Satria Efendi M, Contemporary Islamic Family Law Problems (Jakarta: Pranada Media, 2004.

\section{Interview Data}

Fahima (51 years), Judge of the Religious Court of Sungguminasa Gowa, Interview, Gowa, 9 August 2019.

Muhammad Fitrah (38 years), Judge of the Religious Court of Sungguminasa Gowa, Interview, Gowa, August 6, 2019.

M. Thayyib HP. (49 years old), Religious Court Judge Sungguminasa Gowa, "Interview" on August 8, 2019. 